INTERNATIONAL JOURNAL

How to cite this article:

Bani Atta, A. A., \& Marzuki, A. (2021). Selectivity and market timing ability of mutual fund houses in emerging countries. International Journal of Banking and Finance, 16(1), 21-42. https://doi.org/10.32890/ijbf2021.16.1.2

\title{
SELECTIVITY AND MARKET TIMING ABILITY OF MUTUAL FUND HOUSES IN EMERGING COUNTRIES
}

\author{
${ }^{1}$ Anas Ahmad Bani Atta \& ${ }^{2}$ Ainulashikin Marzuki \\ Faculty of Economics and Muamalat \\ Universiti Sains Islam Malaysia, Malaysia \\ ${ }^{2}$ Corresponding author: ainulashikin@usim.edu.my \\ baniata_anas@hotmail.com
}

Received: 27/7/2020Ｒevised: 28/8/2020 Accepted: 8/9/2020 Published: 30/1/2021

\begin{abstract}
The paper investigates the selectivity and market timing ability of fund houses in emerging countries. The study uses comprehensive performance models on fund houses from four emerging countries. Data span is from 2007 to 2018. Findings indicate that fund managers benefit from the common facilities provided by the fund houses like market research, diversification and investment opportunity. Fund houses showed good selectivity skills but poor market timing ability. The possible reason is that fund houses manage large and different types of funds. This resulted in more complex management processes and thus reduced the ability to track the fluctuations in the market. The findings are important for investors as they are able to allocate their resources more effectively to funds that are best managed by fund houses while for managers, they are able to position themselves relative to their competing peers.
\end{abstract}


Keywords: Mutual fund, fund house, selectivity ability, market timing ability, emerging countries.

JEL Classification: G11, G14, G17, G20, G40

\section{INTRODUCTION}

Fund houses act as financial intermediaries offering a variety of mutual funds under their common brand name and via common marketing and distribution channels (Bani Atta \& Marzuki, 2019). A fund house is a group of funds that is managed by an asset management company (AMC) (Iqbal, Aleemi, Zeeshan, \& Tariq, 2019). The study of mutual fund at the fund house level (instead of at individual fund) is important for several reasons (Nanda, Wang, \& Zheng, 2004).

Firstly, a fund house structure adds economies of scale to the distribution, servicing, and funds promotion. Secondly, a fund house has more flexibility in reallocating its human resources and other capital in response to market opportunities compared with standalone funds. Thirdly, the reputation of a fund house will help reassure investors about the investment managers' selection and monitoring.

The importance of fund house study is evident with increasing reports that provide classification of fund houses in order to create the most effective investment data and research for investors (examples are Morningstar and Barron's). According to the reports of Morningstar and Barron, it is possible to use the fund house performance to provide investors a ranking of the fund houses.

They began reporting on the classification of fund houses using the performance of the fund house (weighted average performance of all funds in the family) to create the most successful investment data and research for investors. The aim of these reports are, firstly, to make it easier for investors to find data about fund houses. Secondly, to remove the information asymmetry and check the statistics provided by the fund houses. Thirdly, provide investors more confidence in the fund house they choose (Laske, 2019).

Globally, the value of asset under management (AUM) of the mutual fund industry was estimated to be worth approximately USD 79.2 
trillion in 2017. The value marked a 12 percent growth from USD 71 trillion in 2016, and it is expected to continue to grow in the future. It is forecasted that the global AUM will triple its value by 2025 (Fages et al., 2018).

A mutual fund is an investment instrument available in many countries across the world. It is essentially an investment basket that collects funds from investors and allocates them into various securities, typically capital and money market instruments. Mutual funds offer a distinctive advantage over retail investors, as it affords the individual investor the opportunity to invest in a diversified basket of securities without the burden of information collection, administration, and other costs (Bani Atta \& Marzuki, 2019). Equity funds make up almost half of these mutual funds. The second and third largest are fixed income and real estate and private equity funds, each constituting respectively 17 and 12 percent of the total.

The prevalence of fund houses underlies the motivation of this study. Investigating the performance of member funds allows one to identify funds with good performance and then determine amongst them the star fund(s). Because fund houses manage a range of funds, each with their respective strategies, measuring the overall performance of the fund house is altogether a different matter (Gasper \& Massa, 2006). Pertinent to the investment decision of the fund are the attributes of the fund house and reputation of the fund house manager. Good reputation emerging from the positive performance of member funds is valuable because it signals the skills of their managers (Adrianto, Chen, \& How, 2019). Thus, the paper addresses the issue of whether fund houses can outperform market benchmarks and if they portray market timing abilities.

This study seeks to contribute in the mutual fund literature by investigating the performance at the fund house level. Most of the previous studies focussed on performance at the individual fund level. It is argued that members of a fund house cannot be treated like standalone funds due to the fact that most of these funds work under the management of the fund house. The performance at the fund house level is important due to most investors using a top-down approach. That means investors firstly choose the fund house and they then choose the funds they will invest in. 


\section{LITERATURE REVIEW}

Investment in mutual funds has been rising rapidly in the developed and emerging markets. Fund performance estimation is a mechanical part of investment management and will include investor input for decision-making purposes. The management seeks to exploit potential market inefficiencies with the goal of optimising returns and mitigating risks through various strategies, such as stock-picking (selectivity of securities) and market timing (price anticipation). This active strategy of management seeks to outperform the market, taking competitive positions towards a benchmark. Several studies have been attempted in the past to investigate the fund's performance, timing ability, and fund selectiveness. In the literature, extensive research has been done on this topic in the general context and in the developed financial markets.

Every mutual fund is managed by a management company called "fund houses". A fund house offers different types of funds to cater to specific objectives of every investor, allowing them to diversify their investments within the same fund house. Fund houses may take on different strategies to attract investment. Malhotra and McLeod (1997) concluded that larger houses enjoy economies of scale and, thus, lower the expense ratio and perform better. This is because houses learn from experience and they operate more efficiently over time. Research by Dowen and Mann (2007) concluded with the same results.

Several studies examined the fund houses' behaviour and strategies (Khorana \& Servaes, 1999; Zhao, 2004; Massa 2003; Guedj \& Papastaikoudi, 2004) and several of them analysed the significance of fund house members on the mutual funds (Elton, Gruber, \& Green, 2007). Khorana and Servaes (1999) provided evidence that fund houses issue new funds when the possibility to generate more income is substantial. Fund houses attempt to offer more choices to existing investors by launching new funds and promote their visibility by highlighting some of their existing good-performing funds. Elton et al. (2007) investigated the risk effect on mutual fund investors which arises from fund houses' membership. They studied the impact of risk related to limiting mutual fund investments to one fund house. They used monthly funds returns from 1998 until 2002, and analysed the mutual fund house's impact on investor risk. The results revealed that 
funds with the same goal are more correlated within the fund houses than between other fund houses. The increased correlation is due to the tendency of funds within a fund house to hold similar stocks and have similar exposure to total risk factors. Then, they postulated that confining investment to one fund house leads to a greater total portfolio risk than diversifying across different houses.

Massa (2003), Guedj and Papastaikoudi (2004) and Gasper and Massa (2006) examined how houses shift performance between their funds. They showed that fund houses pass resources between member funds within the fund house to favour those funds that were likely to increase the total fund house values. Massa (2003) examined how fund houses play a role in determining between-fund competition through either category proliferation of fund strategies.

Fund heterogeneity correlates with between-fund competition between and within houses. After examining more than 18,000 American mutual funds from 1992 to 2000, the author found that the category proliferation strategy positively correlates with fund differentiation. No relationship was found between the proliferation strategy and fund performance, indicating that a fund is independent of its within-fund house peers.

Fund house performance also affects their constituents. Analysing US funds, Guedj and Papastaikoudi (2004) discovered the persistent performance of member funds within their houses. This persistent excess performance is linked to the number of funds in the fund house, which can be interpreted as a measure of autonomy that the fund house exercises in allocating resources unevenly amongst its members.

This finding is congruent with the view that houses allocate resources to its members based on their performance, not needs. This result is supported by Gasper and Massa (2006), who investigated whether fund houses strategically transfer performance to members that are more likely to improve the fund houses' overall return. To do this, they used a sample of USA funds from 1991 to 2001. They discovered that high-value funds, that is, funds with high fees or historically good performers, achieve their superior performance at the expense of low-value funds. These results highlighted how the fund house organisation generates distortions in delegated asset management. 
Clare, O'Sullivan, and Sherman (2014) took a sample of US and European mutual funds from 1999 to 2009 to investigate the competitive and strategic behaviours of fund house funds and to ascertain whether both factors determine risk-taking and performance persistence. They found no evidence to support a superior performance persistence of fund house funds vis-à-vis non-fund house funds. Moreover, based on their historical performance, there is a significant difference between the future performance of fund house and non-fund house funds' portfolios. There is also compelling evidence that the mid-year ranking of a fund within its own fund house and sector influences its risk-taking for the remainder of the year.

Fang, Peress, and Zheng (2014) found the strategies carried out by fund houses to coordinate their fund managers by investigating the relationship between managerial placement strategies and market efficiency. As much as 1,869 US mutual funds in the 1991-2010 decade were made as sample. The authors find that fund houses tend to assign highly-skilled managers to less efficient funds, seeing that such managers have the capability to turn the funds around. Fund houses thus intervene in the managers' duties, and these interventions have the apparent purpose of enhancing the overall value of the fund house instead of maximising investors' investment value. Cici, Dahm, and Kempf (2018) examined how the efficiency of trading desks operated by mutual fund houses affect portfolio performance and investment behaviour of affiliated funds in the US.

The results concluded that by operating more efficient trading desks, trading costs can be reduced, and fund houses can then improve the performance of their funds significantly and enable their funds to trade more and hold less liquid portfolios. Aleemi, Tariq, and Zeesha (2019) examined the effects of fund sizes, mainly the induction of new funds and the increase in existing funds, managed by fund houses on their AUM for the mutual fund industry of Pakistan. This was for the period between July 2009 and July 2016. The main findings suggested that both existing and new fund sizes have a positive and significant impact on AUM. Additionally, fund growth is strongly associated with fund house growth.

On Malaysia, Bani Atta and Marzuki, (2020) investigated the selectivity and timing ability of fund families for the period from 2007 to 2018. They started to compare between Islamic mutual funds 
(IMFs) and conventional mutual funds (CMFs) within the same family, and then examined the performance at the fund family level. The results indicated that the IMFs exhibited some fund selection ability over CMFs. However, both types of funds displayed poor market timing ability. At a fund family level, the results showed the fund families exhibited good fund selection skills but poor market timing ability. The novel result is that the difference in performance between Islamic and conventional funds shrunk compared to the results of previous studies. This was due to the common advantages offered by the families for both types of funds.

Other studies elaborated the behaviour of individual fund managers within fund houses. Kempf and Ruenzi (2007, 2008) concluded that fund managers contest with other fund managers in the same houses for better ranking. It is more serious in large houses than in the smaller ones. Nevertheless, they find that teams in large houses participated in less rivalry. As a summary, the investors appeared to respond asymmetrically to fund performance. Well-performing funds drew higher capital inflows as opposed to small outflows of capital in poor-performing funds. This convex relationship means that assets under the management of a fund house are supposed to be higher if it produces a one-star fund and some poorly performing funds than if it has a few average performing funds. This influence induces the fund house strategy of star fund generation.

We conclude that there is a clear gap in the studies of fund performance at the fund house level. Previous studies focused only on the fund level and the characteristics of fund houses, in addition to investigating the impact of these characteristics on fund performance. This study seeks to bridge this gap by providing new evidence about the performance of fund houses, whether related to fund house managers' skills and ability, and to houses' attributes specifically in the emerging countries (Saudi Arabia, Malaysia, Indonesia and Pakistan).

\section{METHODOLOGY}

\section{Data}

The main source of mutual fund data is collected from Bloomberg. The sample comprises 70 houses. Of this, 25, 20, 14 and 11 fund 
houses are domiciled in Saudi Arabia, Malaysia, Indonesia, and Pakistan, respectively. The total funds in these 70 houses equal to 503 funds. The performance of the fund house equals the weighted average of the performance of all funds in the fund house. The study period is between January 2007 and December 2018, focusing mainly on monthly returns. Relevant benchmarks were also collected from Bloomberg to compare the performance of the fund house under study. The FTSE Global Islamic Index is used for global Islamic benchmark for all countries and the FTSE All-World index is the most relevant for global funds since it covers the largest market capitalisation of global equity markets (Wilson \& Jones, 2002). The risk-free-rate is the 3-month T-bill rate which is used as a risk-free rate in multiple studies that examine mutual funds' performance. Monthly returns are calculated as follows:

$$
\text { Return }_{t}=\frac{\text { price }_{t}-\text { price }_{t-1}}{\text { price }_{t-1}}
$$

Where, price $_{t}$ is the price of an index in period t, price $_{t-1}$ is the price of an index in period $\mathrm{t}-1$.

\section{Selectivity Models}

The selectivity models are one of the most commonly used models for evaluating mutual fund performance. Stock selection models used in this study include raw returns and excess returns as well as risk adjusted measures which are Sharpe ratio, Treynor ratio, Jensen alpha, and Carhart's four-factor models. Joo and Park (2011) and Adrianto et al. (2019) calculated the performance of fund houses as the average performance of all funds in the same fund house. In this study, the fund house performance will be calculated as the weighted average of all funds in the fund house using all measurements.

\section{Raw Returns and Excess Returns}

Raw return is the return for a fund house calculated by the weighted average of raw return of all funds in the fund house.

$$
\text { Raw returns }_{f h, t}=\sum_{i=1}^{n} W_{i} * \text { Raw returns } s_{i}
$$

Where, Raw returns $s_{f h, t}$ is the raw returns for the fund house, $W_{i}$ the weight of fund $i$ calculated by the TNA of fund i divided by 
the TNA of fund house. $\mathrm{N}$ is the number of funds in the fund house. Excess returns are measured using the following equation:

$$
\text { Excess returns }_{f h, t}=R_{f h, t}-R_{f, t}
$$

Where, $R_{f h, t}$ is the raw return of the fund house over the period $t$, $R_{f, t}$ is the risk-free rate of return over the period t.

\section{Sharpe ratio (1966)}

Sharpe introduced a ratio to rank mutual fund performance by deducting the risk-free rate from fund house returns, divided by the standard deviation of fund house returns.

$$
\text { Sharpe }_{f h, t}=\frac{R_{f h, t}-R_{f, t}}{\sigma_{f h, t}}
$$

Where, $R_{f h, t}$ is the mean return of the fund house over the period t, $R_{f, t}$ is the risk-free rate of return over the period t. $\sigma_{f a m, t}$ is the standard deviation of a fund house mean excess return. The Sharpe ratio is widely used as a measure to rank mutual fund performance, especially in recent mutual fund performance studies.

\section{Treynor ratio (1965)}

Treynor ratio is similar to the Sharpe ratio, except it uses the beta as a measure of systematic risk instead of using standard deviation. The Treynor ratio is calculated after subtracting the risk-free rate from the fund house return and dividing it by the beta. The beta is considered the systematic risk between the fund house and the market index. The Treynor model is defined as

$$
\text { Treynor }_{f h, t}=\frac{R_{f h, t}-R_{f, t}}{\beta_{f h, t}}
$$

Where, $R_{f h, t}$ is the mean return of the fund house over the period t, $R_{f, t}$ is the risk-free rate of returns over the period t. $\beta_{f a m, t}$ is the beta coefficient for the fund house, estimating as follows:

$$
\operatorname{Beta}_{f h}=\frac{\operatorname{Cov}\left(R_{f h}, R_{m}\right)}{\operatorname{Var}_{r m}}
$$

Beta is a measure of sensitivity between the market and the fund house. It is calculated by dividing the covariance between the fund house and market return divided by the variance of the market return. 
A higher beta indicates that a fund house is highly associated with the market and is playing a dominant role either with positive or negative returns. Moreover, the higher the Treynor ratio, the better the ranking and fund house performance; it also may indicate that such a fund house is well-diversified.

\section{Single Factor CAPM Model (Jensen, 1968).}

Jensen Alpha is the first risk-adjusted return measure used in this section. Jensen explains how to measure risk-adjusted abnormal performance in the market by capturing the abnormal excess returns of a fund house using Jensen's alpha.

$$
\begin{aligned}
\text { Jensen }_{f h, t}= & \text { Return }_{f h, t}-\text { Return }_{f, t}=\alpha_{i}+ \\
& \beta\left(\text { Return }_{m, t}-\text { Return }_{f, t}\right)+\varepsilon_{f h, t}
\end{aligned}
$$

Where, $R_{f h, t}$ is the return on the fund house, $R_{f, t}$ is the risk-free rate of return, $R_{m, t}$ is the return on the relative market benchmark, $\beta$ measures the sensitivity between the excess return of the market benchmark with the fund house, $\alpha_{i}$ captures any excess returns above market benchmark, $\varepsilon_{i, t}$ while is the term error. The Jensen alpha measures the fund house's over or underperformance; if positive and significant, then the fund house is over-performing and it indicates that managers earned extra returns on the fund house due to stock selection ability.

\section{Carhart Four-Factor Model (1997)}

Carhart expanded the Fama French three-factor model, taking into consideration momentum factor in addition to size and value factors. The Carhart model is defined as follows:

$$
\begin{aligned}
R_{f h, t}-R_{f, t} & =\alpha_{i}+\beta_{1}\left(R_{m, t}-R_{f, t}\right)+\beta_{2} S M B_{t} \\
& +\beta_{3} H M L_{t}+\beta_{4} M O M_{t}+\varepsilon_{f h, t}
\end{aligned}
$$

Where, $R_{f h, t}$ is the mean return of the fund house over the period $\mathrm{t}, R_{f, t}$ is the risk-free rate of return over the period $\mathrm{t}, R_{m, t}$ is the return on the relative market benchmark. $S M B_{t}$ is the difference in return between a small-cap portfolio and a large-cap portfolio at time $t$, $H M L_{t}$ while is the difference in return between a portfolio of high-bookto-market stock and a low-book-to market stock at time t. $\beta_{1}$ measures the sensitivity between the market and the fund house. If it is positive and significant, then the fund house is highly associated with market 
movements, $\beta_{2}$ is a coefficient that measures the fund house exposure, if seen positive and significant then the fund house is associated with small-capitalisation stocks. $\beta_{3}$ a coefficient that measures the fund house exposure and if positive and significant, then the fund house is exposed to high-book-to-market stocks, $\alpha_{i}$ measures the selectivity ability where if positive and significant, then the fund house has superior stock selection ability, $M O M_{t}$ is the different in return between high minus low momentum (prior one year return) at time t. $\beta_{4}$ is the coefficient that measures the fund house's exposure and if positive and significant, then the fund house is exposed to high momentum.

\section{Market Timing Models}

Market timing is measured using the Treynor and Mazuy (TM) (1966) and Henriksson and Merton (HM) (1981) approaches. The aim is to investigate whether fund house managers exhibit market timing ability. Market timing models identify fund house managers' ability to develop timing strategies to shift capital between safe and risky securities based on whether the market is expected to do well or bad. Over-performing fund houses are able to forecast entry and exit strategies in the market for their funds.

\section{Treynor \& Mazuy (TM) Model (1966)}

Treynor and Mazuy (1966) built a model that recognises good market timing of fund houses. The market timing is cached by the square of market returns. The model is as follows:

$$
T M=R_{f h, t}-R_{f}=\alpha_{i}+\beta_{i} R_{m}-R_{f}+\gamma_{i}\left(R_{m}-R_{f}\right)^{2}+\varepsilon_{f h}
$$

Where, $R_{f h, t}$ is the mean return of the fund house over the period $\mathrm{t}, R_{f, t}$ is the risk-free rate of returns over the period $\mathrm{t}, R_{m, t}$ is the return on the relative market benchmark, $\alpha_{i}$ measures selectivity ability, $R_{m, t}{ }^{2}$ is the squared market return, and $\gamma_{i, \mathrm{t}}$ indicates market timing where if positive and significant, then the fund houses are successful and exposure to the market is increased when markets are doing well.

\section{Henriksson \& Merton (HM) Model (1981)}

$$
H M=R_{f h, t}-R_{f, t}=\alpha_{i}+\beta_{i} R_{m, t}-R_{f}+\delta_{i}\left(R_{m}-R_{f}\right) D_{t}+\varepsilon_{f h}
$$


Where $R_{f h, t}$ is the mean return of the fund house over the period $t, R_{f, t}$ is the risk-free rate of return over the period $t, R_{m, t}$ is the return on the relative market benchmark, $\alpha_{i}$ measures selectivity ability, $\delta_{i}$ is the market timing coefficient, $D_{t}$ is a dummy variable that takes a value of one if the market return is positive and zero otherwise, and $\varepsilon_{f a m, t}$ is the error term.

\section{ANALYSIS OF RESULTS}

This section provides the results for the analysis of fund houses' performance which include fund house managers' selectivity and timing ability performance.

\section{Descriptive Statistics}

Table 1 presents the descriptive statistics of monthly returns of the fund house, market benchmarks, and other risk factors from 2007 to 2018. As shown in Table 1, the empirical characteristics of negative skewness, excess kurtosis, and non-normality in most portfolio returns are the dominant features of the data. The mean of fund houses' returns is positive and equal 0.0920 . While the mean returns for Islamic and conventional benchmarks are negative and equal -0.0615 and -0.0061 , respectively.

\section{Table 1}

Descriptive Statistics

\begin{tabular}{lrrrrrrr}
\hline & $\begin{array}{c}\text { Fund } \\
\text { house }\end{array}$ & $\begin{array}{c}\text { FTSE } \\
\text { Islamic }\end{array}$ & $\begin{array}{c}\text { FTSE } \\
\text { all } \\
\text { world }\end{array}$ & SMB & HML & MOM & TB \\
\hline Mean & 0.092 & -0.062 & -0.006 & -0.080 & 0.046 & -0.019 & 0.065 \\
Med. & 0.132 & -0.063 & -0.003 & 0.132 & -0.156 & 0.209 & 0.063 \\
Max. & 0.693 & 0.458 & 0.117 & 0.184 & 0.429 & 0.209 & 0.139 \\
Min. & -0.583 & -0.454 & -0.235 & -0.406 & -0.156 & -0.925 & 0.018 \\
SD. & 0.037 & 0.057 & 0.047 & 0.281 & 0.267 & 0.519 & 0.030 \\
Skew & -1.158 & -1.982 & -0.657 & -0.219 & 0.669 & -0.645 & 0.521 \\
Kurt. & 25.763 & 24.796 & 1.863 & -1.881 & -1.483 & -1.520 & 1.489 \\
& & & & & & & \\
\hline
\end{tabular}


Table 2 displays the Pearson correlation coefficients of the fund house, and the risk factors, and also below the correlation coefficients are $\mathrm{p}$-value for tests of significance of coefficients. This is to check if the problem of multicollinearity exists. Fund house returns indicate a low correlation with returns of both markets' benchmarks of FTSE Global Islamic and FTSE All-World. Similarly, the market indices show low correlation with each other, with significantly positive correlation coefficients. None of the variables or independent variables are highly correlated. The highest reported figure is 30.46 percent, the correlation between FTSE Islamic returns and Treasury bill rate. Hence, the estimation is less likely to suffer the multicollinearity problem.

\section{Table 2}

Correlation Matrix

\begin{tabular}{lrrrrrrr}
\hline & $\begin{array}{c}\text { Fund } \\
\text { house }\end{array}$ & FTSE (I) & $\begin{array}{r}\text { FTSE } \\
(\text { AW) }\end{array}$ & SMB & HML & MOM & TB \\
\hline Fund house & 1.000 & & & & & & \\
FTSE (I) & -.030 & 1.000 & & & & & \\
FTSE & .002 & & & & & & \\
(AW) & -.083 & .085 & & & & & \\
& .000 & .000 & 1.000 & & & & \\
SMB & .002 & .001 & .149 & & & & \\
& .041 & .055 & .000 & 1.000 & & & \\
HML & .007 & .051 & .128 & .064 & & & \\
& .047 & .000 & .000 & .000 & 1.000 & & \\
MOM & -.010 & -.068 & -.161 & -.055 & -.418 & 1.000 & \\
& .029 & .000 & .000 & .000 & .000 & \multicolumn{1}{l}{} \\
TB & .044 & -.305 & -.109 & -.007 & -.025 & .015 & 1.000 \\
& .000 & .000 & .000 & .439 & .011 & .138 & \\
\hline
\end{tabular}

\section{Selectivity Skills Models}

This section reports the finding of the empirical analysis of six performance measures to gauge the performance of the fund house comparative to benchmarks. The performance measures used are: raw returns, excess returns, the Sharpe ratio, the Treynor ratio, the one factor model (Jensen's alpha), and the Carhart's four-factor model. 


\section{Raw Return, Excess Return, the Sharpe Ratio, and the Treynor Ratio}

Table 3 presents monthly means for raw returns and excess returns, the Sharpe ratio and Treynor ratio for the fund house. The fund houses' performance are compared using two market indices. The mean raw returns for fund houses are 0.07 percent per month, and for Islamic and conventional benchmarks are 0.003 and 0.002 percent per month, respectively. However, after taking into account the risk-free rate, the mean excess returns of fund houses remain positive at 0.009 percent per month, but the mean excess returns for both market benchmarks which are Islamic and conventional are negative at -0.061 and -0.082 , respectively. Both the mean returns and mean excess returns for fund houses are higher than both the market benchmarks. Although the fund houses' returns exceed the returns of the market benchmarks, the returns are less volatile. In addition, the beta of fund houses is lower than that of market beta (1.000). This gives an initial indicator of the attractiveness of fund houses that yield higher returns but lower risks, both total and systematic. This could be due to the diversification which are provided by the houses.

The Sharpe ratio represents the calculation of mean excess returns relative to the total risk indicated by the standard deviation. This measure gives the unit of return earned while taking an additional unit of total risk. The results indicate that investment in fund houses earn a Sharpe ratio of 0.39 percent per month, but the Sharpe ratio for both market benchmarks is negative -1.08 and -1.34 , respectively. That means the investment in fund houses is better than investment in both market benchmarks Islamic and conventional. The Treynor ratio refers to the calculation of mean excess returns relative to the systemic risk posed by beta. The Treynor ratio shows positive results using both market benchmarks. That means the fund houses show better performance and are well diversified.

The findings of these essential performance models are used to conclude that the fund house outperforms both the market benchmarks when relative performance measures are used. This is justified by the increased diversification provided by houses which in turn offers advantages of improving the overall performance of fund houses. This corresponds to the modern portfolio theory (MPT) which suggests that the risk-reduction advantages associated with maintaining a diversified portfolio of assets are that it maximises the anticipated 
return based on a given degree of market risk. Although the relative performance measures are commonly used in practice, these measures can only be used in ranking funds in relation to their peers in that they provide no fundamental statistical or economic meaning. Therefore, the next sections provide the results of the single and multi-factor models. These performance models, based on the CAPM, give an estimate of the intercept (alpha), which refers to fund performance in relation to the benchmark return.

\section{One Factor Model (Jensen, 1968)}

Table 4 provides the results for the analysis of performance employing the one-factor model (Jensen, 1968) using both market benchmarks, FTSE Global Islamic and FTSE All-World. Alpha indicates the monthly abnormal returns of the fund houses. As shown, the alpha estimate for fund houses is positive and equals 0.19 percent per month for FTSE Global Islamic and 0.20 percent per month for FTSE AllWorld. That indicates that the fund houses outperformed both market benchmarks. This result is also in line with the results of the traditional measures in the previous section.

\section{Table 3}

Mean Raw Returns, Mean Excess Returns, Sharpe Ratio, and Treynor Ratios

Fund House FTSE Islamic FTSE All World

Panel A: Mean raw, mean excess return, and Sharpe ratio

$\begin{array}{lrrr}\text { Mean raw returns } & 0.0740 & 0.0032 & 0.0023 \\ \text { Mean excess return } & 0.0093 & -0.0615 & -0.0824 \\ \text { Std. Dev } & 0.0317 & 0.0569 & 0.0465 \\ \text { Sharpe ratio } & 0.3936 & -1.0812 & -1.3424\end{array}$

Panel B: Beta and Treynor ratio using FTSE Islamic as benchmark

\begin{tabular}{lccc} 
Beta & 0.1307 & 1.0000 & ----- \\
Treynor & 0.0711 & ----- & ----- \\
Panel C: Beta and Treynor ratio using FTSE All world as benchmark \\
Beta & 0.1166 & ------ & 1.0000 \\
Treynor & 0.0797 & ------ & ----- \\
\hline
\end{tabular}


The adjusted $\mathrm{R}^{2}$ for fund houses are 81 percent and 85 percent for FTSE Global Islamic and FTSE All-World, respectively. The high adjusted $\mathrm{R}^{2}$ also indicates that the fund managers pursue a passive approach by watching the market closely, but are unable to perform well. The results also show the alpha using a conventional benchmark is better than the alpha using the Islamic benchmark, that due to some restrictions are placed on Islamic investments that may limit performance.

\section{Table 4}

One Factor Model (Jensen, 1968)

\begin{tabular}{lcccccc}
\hline & \multicolumn{2}{c}{ FTSE Global Islamic } & \multicolumn{2}{c}{ FTSE All World } & \\
& Alpha & Beta & Adj. R & Alpha & Beta & Adj. R ${ }^{2}$ \\
\hline Coeff & 0.1942 & -0.2435 & 0.81 & 0.2025 & -0.1067 & 0.85 \\
Std.err & 0.0072 & 0.0801 & ----- & 0.0077 & 0.0916 & ----- \\
$p$-value & 0.0002 & 0.0023 & ----- & 0.0001 & 0.2441 & ----- \\
\hline
\end{tabular}

Source: Jensen (1968).

\section{Four-Factor Model (Carhart, 1997)}

For the four-factor model, the factor returns for the four-factor models are not easily available, hence the researcher used the data made available at the Fama and French websites, which in turn employs the FTSE All-World database to construct monthly for the four-factor model. Table $\mathrm{V}$ provides the results of the four-factor model for fund houses using FTSE All-World as a market benchmark. As shown in Table 5, the four-factor alpha for fund houses was 0.20 percent and significant, which indicates that on average, the fund houses are able to outperform the four-factor benchmarks. In addition, the results indicate that the fund houses exhibit lower risks with beta of -0.14 . This result is similar to the results using the one-factor model.

In terms of size preference, fund houses prefer small stocks than big stocks, given the SMB factor loading is -0.03 and statistically significant. The HML factor for fund houses is -0.05 and statistically significant, suggesting a preference for growth-to-value stock. The 
MOM factor for fund houses is not significant. The fund houses display a relative preference for small-cap and growth-oriented stock. In conclusion, the preference of fund houses for smaller cap and lower beta results in the significant out-performance of fund houses over the four-factor benchmarks. Fund houses also display a preference for the growth-to-value stock. Finally, the MOM factor for fund houses is not significant.

Fund houses' superior performance can be attributed to that the fund houses remove unsystematic risks by diversification, which means the houses make funds work within these houses comprising only market risks (systematic risks). This should make for a stronger relationship, if there is one, in any subsequent time-series regression, especially if there is time-series autocorrelation. The constant or error term in the subsequent regression helps to remove any remaining unsystematic risk.

\section{Table 5}

Carhart's Four Factor Model

\begin{tabular}{lccc}
\hline & Coef & Std.err & $p$-value \\
\hline Alpha & 0.2011 & -0.0079 & 0.0001 \\
Market & -0.1400 & 0.0974 & 0.0505 \\
SMB & -0.0336 & 0.0023 & 0.0488 \\
HML & -0.0538 & 0.0022 & 0.0015 \\
MOM & -0.0022 & 0.0017 & 0.2042 \\
Adj. $\mathrm{R}^{2}$ & ---- & 0.88 & ----- \\
\hline
\end{tabular}

\section{Market Timing Models}

Table 6 presents the results for the analysis of security selection and market timing ability using the Treynor-Mazuy model (TM) and Hendrickson-Merton model (HM) using ordinary least square (OLS), for fund houses. In the panel "A", according to the Treynor-Mazuy model (TM), fund houses have good selectivity skills but appear to have poor market timing ability irrespective of the benchmarks using 
both market benchmarks "FTSE Global Islamic and FTSE All-World". Alpha is positive and equals to 0.195 and 0.193 , respectively, and Gamma is negative and equals to -0.12 and -0.34 , respectively. In the panel "B", according to the Hendrickson-Merton model (HM), fund houses have good selectivity skills but appear poor in market timing ability irrespective of the benchmarks using both market benchmarks "FTSE Global Islamic and FTSE All-World". Alpha is positive and equals to 0.19 and 0.20 , respectively, and Gamma is negative and equals to -0.08 and -0.30 , respectively.

\section{Table 6}

Market Timing Models: Treynor-Mazuy Model and HendricksonMerton Model

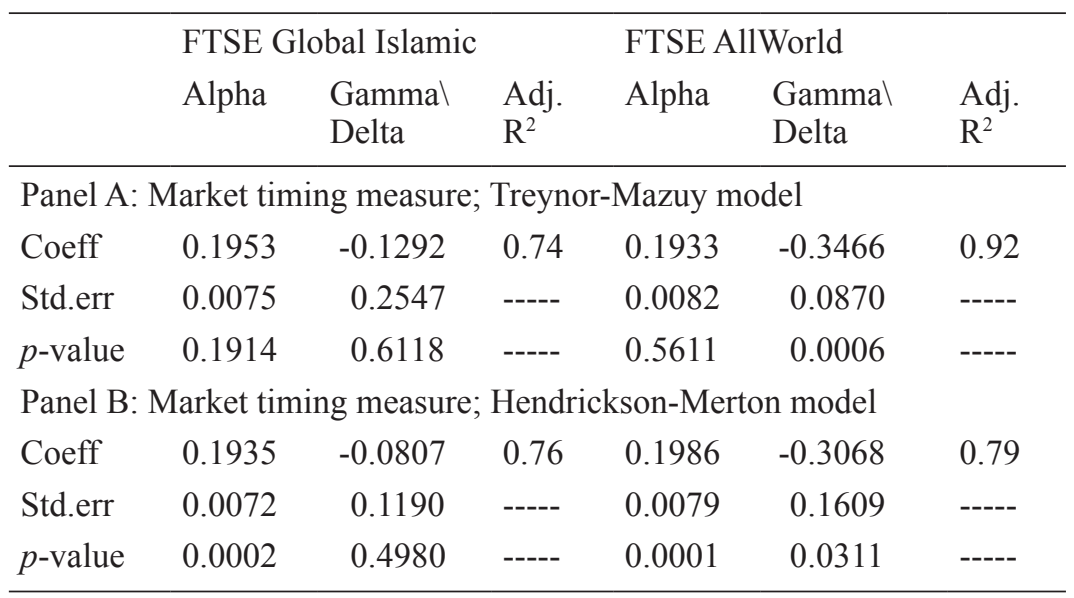

Overall, both market timing ability measures (Treynor-Mazuy model (TM) and Hendrickson-Merton model (HM)) provide similar results, where there is strong evidence that fund house managers have good selectivity skills and this results in supporting results of the one-factor and four-factor models. This is due to the benefits provided by the advantages of fund houses like diversification and more investment opportunities. However, fund houses have weak market timing ability. The possible reason is that the fund houses contain large and different types of funds, and thus the management process becomes more difficult. This may reduce the ability and efficiency of managers. 


\section{CONCLUSION}

This study seeks to contribute by providing new evidence about the mutual fund performance at the fund house level. Firstly, the study concluded that managers benefit from the advantages provided by the fund house like diversification and more investment opportunity. So, fund house managers show good selectivity skills. At the same time, fund house managers show poor market timing ability. The possible reason is that the fund houses contain large and different types of funds, and thus the management process becomes more difficult. This may reduce the ability and efficiency of managers to track the fluctuations and constant movements in the market.

The results are useful for both investors and managers. Managers should take the requisite decision or changes to make themselves more efficient in comparison with their competing colleagues. The investors can more effectively allocate their money to better controlled funds. In addition, the results help investors make the correct investment decision, since most of the investors use the top-down approach. The results are also important to academics and regulators because they provide an overview of the mutual fund industry generally, and fund houses specifically.

From the results of this study, there are two recommendations that must be considered. Firstly, due to limited evidence about performance at the fund house level, it is important to increase the focus upon the fund house level because the advantages of fund houses may lead to improved performance as the results showed.

It is then highly recommended to extend the focus to characteristics of these houses and their effects on houses and funds' performance. Secondly, since most of the previous studies focussed on developed countries like the USA and UK, then it is highly recommended to academics and researchers to extend such studies to other emerging countries like the Middle-East and South-Asia countries.

\section{ACKNOWLEDGMENT}

This research received no specific grant from any funding agency. 


\section{REFERENCES}

Adrianto, F., Chen, E., \& How, J. C. Y. (2019). Spillover effects in SRI fund families. https://ssrn.com abstract=3311876.doihttp:// dx.doi.org/10.2139/ssrn.3311879.

Aleemi, A. R., Tariq, M., \& Zeeshan, M. (2019). Funds induction, flows and family growth: The dynamics of asset management companies. Forthcoming in Pakistan Business Review, 20(4). 926-940.

Bani Atta, A. A. B., \& Marzuki, A. (2019). The impact of funds and fund family characteristics on fund performance: Evidence from Malaysia. Journal of Wealth Management \& Financial Planning, 6(June), 3-23.

Bani Atta, A. A. B., \& Marzuki, A. (2019). The determinants of Islamic mutual fund flows: Evidence from Malaysia. International Journal of Advanced Research in Economics and Finance, $1(1), 10-21$.

Bani Atta, A. A. B., \& Marzuki, A. (2020). Islamic versus conventional funds within the family: Selectivity skills and market timing ability. Journal of Islamic Monetary Economics and Finance, 6(2), 1-24.

Carhart, M. M. (1997). On persistence in mutual fund performance. The Journal of Finance, 52(1), 57-82.

Cici, G., Dahm, L. K., \& Kempf, A. (2018). Trading efficiency of fund families: Impact on fund performance and investment behaviour. Journal of Banking and Finance, 88, 1-14.

Clare, A., O'Sullivan, N., \& Sherman, M. (2014). Family status and mutual fund performance. Journal of Asset Management, 15(3), $163-175$.

Dowen, R. J., \& Mann, T. (2007). Do investors benefit from 12b-1 Fees? American Journal of Business, 22(1), 21-30.

Elton, E. J., Gruber, M. J., \& Green, T. C. (2007). The impact of mutual fund family membership on investor risk. Journal of Financial and Quantitative Analysis, 42(2), 257-277.

Fages, R., Beardsley, B., Brömstrup, I., Donnadieu, H., Macé, B., Pardasani. (2018). Global Asset Management 2018: The Digital Metamorphosis.

Fang, L. H., Peress, J., \& Zheng, L. (2014). Does media coverage of stocks affect mutual funds' trading and performance? Review of Financial Studies, 27(12), 3441-3466. 
Gaspar, J., \& Massa, M. (2006). Favouritism in mutual fund families? Evidence on strategic cross-fund subsidisation. The Journal of Finance, 61(1), 73-104.

Guedj, I., \& Papastaikoudi, J. (2003). Can mutual fund families affect the performance of their funds? https://ssrn.com/ abstract $=467282$.

Henriksson, R. D., \& Merton, R. C. (1981). On market timing and investment performance. II. Statistical procedures for evaluating forecasting skills. Journal of Business, 54(4), 513-533. doi: 10.1086/296144.

Jensen, M. C. (1968). The performance of mutual funds in the period 1945-1964. The Journal of Finance, 23(2), 389-416.

Joo, H. K., \& Park, Y. K. (2011). Contribution of star funds to fund families: An empirical analysis of the korean fund market. Asia-Pacific Journal of Financial Studies, 40(5), 731-762.

Kempf, A., \& Ruenzi, S. (2007). Tournaments in mutual-fund families. Review of Financial Studies, 21(2), 1013-1036.

Kempf, A., \& Ruenzi, S. (2008). Family matters: Rankings within fund families and fund inflows. Journal of Business Finance and Accounting, 35(1-2), 177-199.

Khorana, A., \& Servaes, H. (1999). The determinants of mutual fund starts. The Review of Financial Studies, 12(5), 1043-1074.

Laske, M. (2019). Morningstar fund family 150 research on the 150 largest U.S. fund families. Morningstar Research Services Report. https:// morning star direct. morningstar. com/ clientcomm/Due DiligenceReports/FundFamily150.pdf.

Malhotra, D. K., \& McLeod, R. W. (1997). An empirical analysis of mutual fund expenses. Journal of Financial Research, 20(2), $175-190$.

Massa, M. (2003). How do family strategies affect fund performance? When performance-maximisation is not the only game in town. Journal of Financial Economics, 67(2), 249-304.

Nanda, V., Wang, Z. J., \& Zheng, L. (2004). Family values and the star phenomenon: Strategies of mutual fund families. The Review of Financial Studies, 17(3), 667-698.

Sharpe, W. F. (1966). Mutual fund performance. The Journal of Business, 39(1), 119-138.

Treynor \& Mazuy. (1966). Can mutual funds outguess the market? Harvard Business Review, 44(4), 131-136. 
Treynor, J. L. (1965). How to rate management of investment funds. Harvard Business Review, 43(1), 63-75.

Wilson, J. W., \& Jones, C. P. (2002). An analysis of the S \& P 500 index and cowles's extensions: Price indexes and stock returns. 1870_1999. The Journal of Business, 75(3), 505-533.

Zhao, X. (2004). Why are some mutual funds closed to new investors? Journal of Banking and Finance, 28(8), 1867-1887. 